\title{
INFLAMMATION AND CLINICAL REPERCUSSIONS OF PLEURODESIS INDUCED BY INTRAPLEURAL TALC ADMINISTRATION
}

\author{
Eduardo Henrique Genofre, Evaldo Marchi, Francisco S. Vargas
}

Genofre EH, Marchi E, Vargas FS. Inflammation and clinical repercussions of pleurodesis induced by intrapleural talc administration. Clinics. 2007; 62(5):627-34.

Although reports on pleurodesis date back to the beginning of the 20th century, the search for the ideal sclerosing agent is ongoing. Several agents have been studied and used, but talc continues to be the most popular. However, potentially harmful systemic side effects have been associated with talc pleurodesis. In this article we discuss the likely mechanisms of pleural inflammation and pleurodesis with emphasis on the systemic response due to the instillation of talc into the pleural space.

KEY-WORDS: Talc. Pleurodesis. Inflammation. Pleura. Pleural effusion.

Pleural effusion is a frequent manifestation, in part because of the increase in the incidence of cancer and, mainly, because of the survival of patients with malignant neoplasms. ${ }^{1,2}$ Since the presence of pleural effusion is indicative of disseminated disease and limited survival, the main objective of treatment is to offer a better quality of life to the patients, relieving symptoms basically characterized by dyspnea and pain. ${ }^{2}$ In addition, since systemic treatment frequently does not control the disease, the local approach to pleural effusion (in addition to drainage of the cavity for immediate improvement of manifestations) is the control of recurrence by sclerosis and symphysis of the pleural membranes, a process called pleurodesis.

The first reports on pleurodesis date back to the beginning of the 20th century, ${ }^{3}$ and although more than 100 years have passed since then and different agents have been employed, the search for the ideal sclerosing agent continues. ${ }^{4}$ Some antibiotics have demonstrated a sclerosing effect (tet-

Laboratory of Pleura, Pulmonary Division - Heart Institute (InCor)University of São Paulo Medical School, Brazil

Email: ehgenofre@uol.com.br

Received for publication on April 16, 2007

Accepted for publication on June 28, 2007 racycline), ${ }^{5}$ whereas no marked efficacy has been observed for others (macrolides and quinolones). ${ }^{6}$ Similarly, antineoplastic agents (bleomycin), ${ }^{7}$ immunostimulants (Corynebacterium parvum and OK-432), ${ }^{8,9}$ chemical irritants (talc and silver nitrate), ${ }^{10,11}$ and more recently, biological mediators of inflammation (transforming growth factor-beta (TGF- $\beta$ ) and interferon) ${ }^{12,13}$ have been effective in the production of pleurodesis. The use of povidone-iodine, ${ }^{14} \mathrm{au}-$ tologous blood, ${ }^{15}$ and polidocanol ${ }^{16}$ has also been reported in some studies.

Among the different substances proposed for the induction of pleurodesis, talc is the agent most used in clinical practice. Talc, a magnesium silicate hydroxide $\left[\mathrm{Mg}_{3} \mathrm{Si}_{4} \mathrm{O}_{10}(\mathrm{OH})_{2}\right]$, has become popular because of its wide availability and high therapeutic success rate, which is close to $90 \% .{ }^{17}$ Talc is applied to the pleural space by injection in saline solution (slurry) or by dusting during pleuroscopy (poudrage). ${ }^{18}$

However, despite its widespread use, the instillation of talc is not devoid of side effects, including chest pain, fever, arrhythmias, and dyspnea. ${ }^{18-20}$ Dyspnea is the most feared side effect because in more severe cases, this condition may result in acute respiratory distress syndrome, with an incidence reaching $9 \%$ and a potentially fatal outcome. $^{20,21}$ 


\section{Systemic effects of talc}

The mechanisms underlying the systemic effects of talc, especially respiratory distress syndrome, are still unknown. The possible and most likely causes include the migration of talc particles from the pleural cavity to the systemic circulation, changes provoked by the different talc components (including the presence of contaminating agents), establishment of an intracavity inflammatory process (source of inflammatory mediators), and surgical procedures performed (biopsies) that provide an access route that facilitates the systemic absorption of talc and inflammatory mediators. ${ }^{22-25}$

\section{Migration of talc from the pleura to the systemic circulation}

Considering the extensive surface of the human pleural cavity ( $\cong 1$ to $\left.2 \mathrm{~m}^{2}\right),{ }^{26}$ as well as the efficient drainage system of the cavity by pleural lymphatic vessels, the hypothesis that absorption of talc particles plays a role in the genesis of systemic effects should be taken into account. ${ }^{23}$ Studies have shown heterogeneity in particle size among talc preparations used for pleurodesis. ${ }^{27}$ Accordingly, one may speculate that smaller particles are more likely to be absorbed by the systemic circulation, causing the adverse effects described..$^{24,25,27}$

In 1999, Werebe et al, ${ }^{28}$ studying the dissemination of talc (particles measuring 5.7 to $70 \mu \mathrm{m}$ ) in rats, observed the presence of talc in bronchoalveolar lavage fluid and different organs (brain, liver, spleen, heart, and contralateral lung). Subsequently, in 2002, Ferrer et $\mathrm{al}^{27}$ compared the induction of pleurodesis in rabbits using talc commonly employed in pleurodesis (particles of $\cong 8.3 \mu \mathrm{m}$ ) and talc with particles of a larger size $(12 \mu \mathrm{m})$. The authors observed talc particles in the mediastinum pericardium and liver. Pleural inflammation and talc deposition were greater in the group receiving smaller particles. In the same year, Fraticelli et al, ${ }^{29}$ using talc with larger particles (mean of $33 \mu \mathrm{m}$ ), identified the presence of a few talc particles in the brain, liver, and spleen, and a cross-contamination of these tissues during storage and processing of the samples was not excluded as a possible cause of the presence of talc in these tissues.

Our group also investigated the extrapleural dissemination of talc particles in rabbits, comparing small talc (mean particle size: $4.2 \mu \mathrm{m}$, with $50 \%$ of particles $<5 \mu \mathrm{m}$ ) and mixed talc (mean particle size: $25.4 \mu \mathrm{m}$, with $90 \%$ of particles $>10 \mu \mathrm{m}$ ) (Figure 1). We found talc deposition in the contralateral lung, liver, kidneys, and spleen, with a larger amount being observed in animals injected with talc comprised of small particles..$^{30,31}$

\section{Talc composition and contaminants}

Another possible cause of systemic alterations is differences in talc composition, which varies in the amount of calcium, aluminum, and iron according to its origin. Similarly, mineral contaminants may produce local and systemic effects, with emphasis on the presence of magnesite, dolomite, caolinite, calcite, chlorite, serpentine, and quartz. $^{32}$

\section{Intracavity inflammatory process}

Another possible cause of systemic side effects is the intense inflammatory process that is observed in the pleural space after talc application, producing cytokines, adhesion molecules, and other mediators of inflammation. ${ }^{24,33}$

The presence of local and systemic inflammatory alterations has been demonstrated in humans undergoing talc pleurodesis. In these patients, impaired DTPA clearance and changes in the alveolar-arterial oxygen gradient and serum

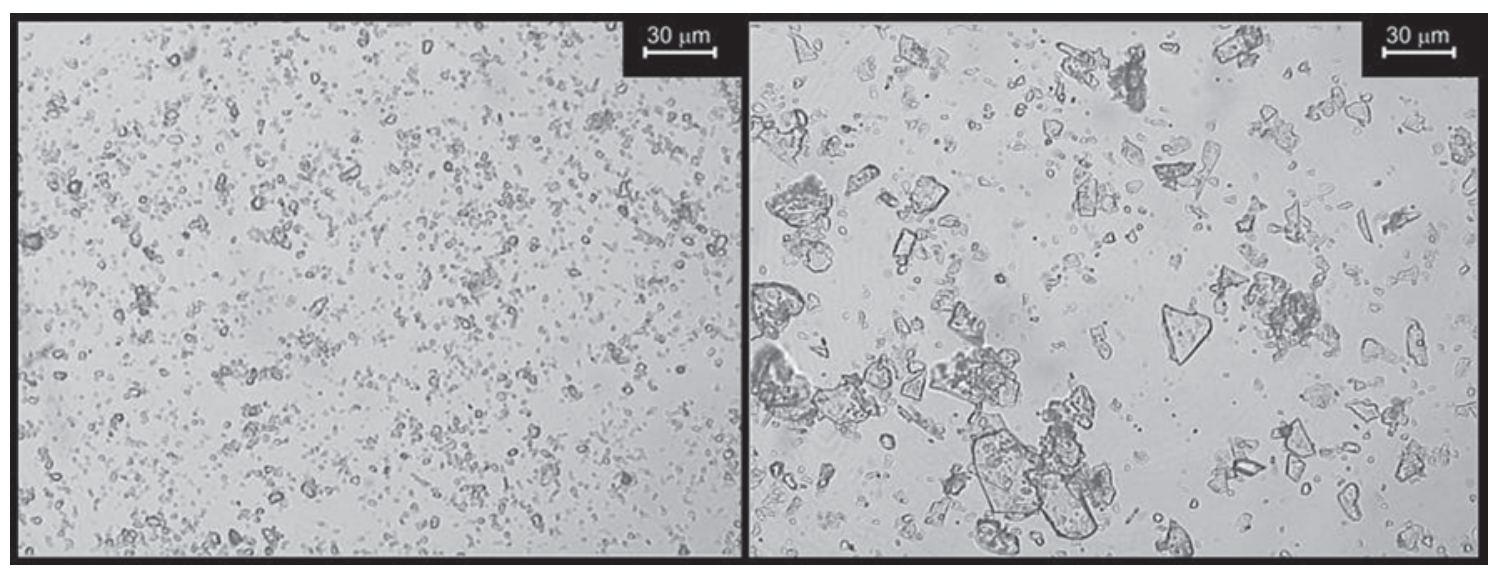

Figure 1 - Talc samples used. Left, talc containing small particles $(<5 \mu \mathrm{m})$. Right, mixed talc $(90 \%$ of particles $>10 \mu \mathrm{m})$. Magnification: $\mathrm{x} 400$ 
C-reactive protein levels were observed. ${ }^{34,35}$ Additionally, chest computed tomography and positron emission tomography demonstrated alterations characteristic of acute pleural inflammation related to the loss of the integrity of the pleural barrier, consequently facilitating the absorption of talc particles and inflammatory mediators. ${ }^{36}$

\section{Inflammatory response}

The chain of events that leads to the occurrence of local and systemic effects is triggered by the inflammatory response to talc components or contaminants or even to inflammatory mediators produced as a result of intrapleural talc administration. ${ }^{37}$ Thus, the understanding of this response is of great importance, taking into account cytological (particularly the acute response mediated by leukocytes and neutrophils), biochemical, and cytokine parameters. Analysis of the the response of leukocytes, and particularly that of neutrophils, is justified by the fact that a cellular response predominates in the pleural cavity, with lactate dehydrogenase being the main enzyme reflecting manifestations of an acute exudate. ${ }^{37}$

\section{Main components}

The inflammatory chain involves the production and release of modulatory substances that act on the producing cells themselves. In this respect, the key function of mesothelial cells was formerly believed to be the protection against aggression, with these cells being regarded as lining cells functioning as structural barriers. However, it is now known that mesothelial cells are not simple passive participants but are in fact responsible for the orchestration of the entire intrapleural inflammatory response, acting on the regulation of the production of diverse mediators such as interleukin 8 (IL-8), vascular endothelial growth factor (VEGF), and TGF- $\beta .^{37}$

The predominant characteristics of IL- 8 , a cytokine involved in the acute inflammatory response, are neutrophil chemotaxis and marked resistance to proteolysis, with this cytokine also being associated with leukocyte activity during inflammatory processes in the pleural cavity. ${ }^{38}$

Vascular endothelial growth factor has 2 main properties, ie, the capacity to increase capillary permeability and a marked angiogenic and lymphogenic potential. It is present in inflammation areas and is found to be increased in exudative effusions, with this factor being implicated in the genesis and maintenance of pleural effusion. ${ }^{37}$

Tumor growth factor-beta presents profibrotic and immunomodulatory properties. Animal studies have demonstrated that TGF- $\beta$ stimulates collagen synthesis and in- duces pleurodesis without causing acute inflammatory effects. Injection of TGF- $\beta$ into the pleural space of rabbits increases VEGF levels in pleural fluid, and in vitro studies have shown that TGF- $\beta$ stimulates the production of VEGF by mesothelial cells. ${ }^{38}$

\section{Types of talc and inflammation}

One of the main hypotheses raised to explain the systemic effects observed in pleurodesis is the migration of talc particles. Accordingly, smaller particles are believed to cause a more intense acute systemic inflammatory response than talc with particles of larger sizes. However, in fact, irrespective of particle size, talc injected into the pleural cavity produces an acute systemic response, with the presence of talc particles being rapidly detected in various organs (24 hours after intrapleural injection). Nevertheless, serum and pleural fluid inflammatory parameters indicate that small-particle talc $(<5 \mu \mathrm{m})$ produces a more prolonged and more intense systemic and pleural response..$^{28,39}$ Therefore, talc administration leads to an increase in the serum levels of IL-8, VEGF, and TGF- $\beta$ and in pleural levels of IL-8 and VEGF, irrespective of particle size, with these levels being more elevated when small-particle talc is injected. ${ }^{30}$ Nasreen et $\mathrm{al}^{40}$ demonstrated that mesothelial cells stimulated by talc produce adhesion molecules and cytokines, emphasizing the importance of talc for the mechanism of pleural inflammation in pleurodesis.

In clinical studies, Maskell et al ${ }^{35}$ demonstrated that talc of varying particle size $(50 \%$ of particles $<10 \mu \mathrm{m})$ exerts more pronounced effects on the lung clearance of DTPA and serum IL-8 and C-reactive protein levels than tetracycline, in addition to causing more lung and systemic alterations. Another study of the same group compared pleurodesis obtained with mixed talc and graded talc in which $50 \%$ of the particles were smaller than $20 \mu \mathrm{m}$, with most particles smaller than $10 \mu \mathrm{m}$ being removed for homogenization of the sample. Measuring the alveolar-arterial oxygen gradient and C-reactive protein levels, the authors demonstrated more systemic and lung inflammation, accompanied by worsened gas exchange, in pleurodesis induced with small-particle talc. The final outcome of pleurodesis was the same after 3 months $(85 \%$ success in both groups). ${ }^{34}$ Recently, Froudarakis et $\mathrm{al}^{41}$ evaluated the role of talc in the systemic inflammatory response comparing diagnostic thoracoscopy and thorascopic talc poudrage. Talc was found to actively participate in the systemic reactional process, causing an increase in leukocyte count and in the percentage of neutrophils, associated with fever. In addition, C-reactive protein levels were significantly higher in the group submitted to talc poudrage. 
The above mentioned facts are important, since no standardization exists for talc production, and there is a wide variation in the composition and particle size among the various talc preparations used worldwide. This fact has been demonstrated by Ferrer et al, ${ }^{27}$ who attributed side effects to the smaller size of the particles in the talc used in different services. A similar efficacy of pleurodesis was reported by the same group when comparing $200 \mathrm{mg} / \mathrm{kg}$ of talc used in clinical practice (particle diameter: $8.36 \pm 0.20$ $\mu \mathrm{m})$ and talc with particles of larger size (diameter: $12 \pm$ $0.25 \mu \mathrm{m})$, but pleural inflammation was greater when the injected talc contained smaller particles..$^{27,32}$ Montes et al, ${ }^{25}$ comparing 2 different talc doses (50 or $200 \mathrm{mg} / \mathrm{kg}$ ), noted a more intense systemic response with the higher dose, including an increase in the number of lymphocytes, monocytes, neutrophils, and platelets.

The more intense pleural inflammation and the more prolonged systemic response observed after the administration of small talc $(50 \%$ of particles $<5 \mu \mathrm{m})$, leads to different speculations regarding the possible mechanisms of inflammation. We believe that the greater pleural inflammatory response observed after the administration of talc containing small particles is a consequence of the larger number of particles per area in the cavity. Furthermore, smaller particles probably are more easily engulfed by inflammatory cells present in the pleural space, in the absence of intense cellular necrosis, a fact that might explain the observation of a larger number of intact neutrophils, the lower lactate dehydrogenase levels, and the more marked release of inflammatory mediators (cytokines). On the other hand, mixed talc $(90 \%$ of particles $>10 \mu \mathrm{m})$ presents a rough spike-like shape and may cause more intense damage to mesothelial cells by a direct mechanical action, resulting in greater cellular necrosis accompanied by increased lactate dehydrogenase levels. ${ }^{30}$
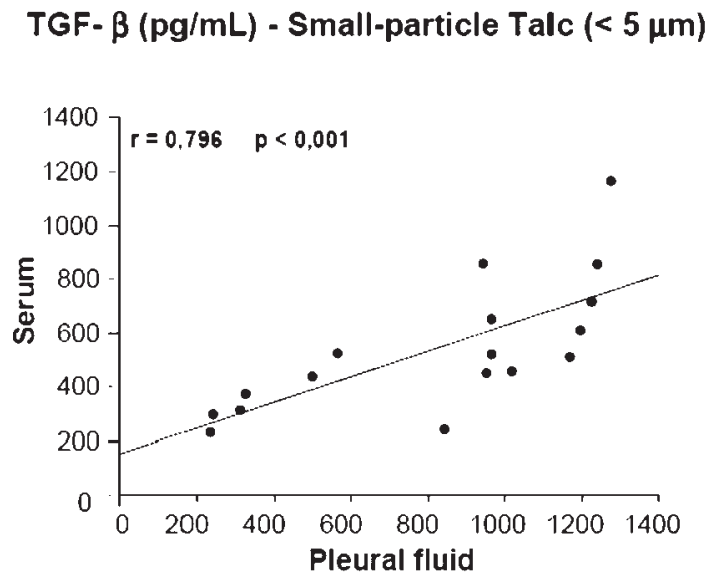

\section{Systemic inflammatory response}

Regardless of the type of talc used, the systemic response observed in pleurodesis is believed to be the result of the passage of inflammatory mediators or talc particles from the pleura to the blood circulation. This passage may occur through the lymphatic route ${ }^{23,26,27}$ (drainage into the venous system and deposition in the lungs) or by direct passage into the bloodstream due to the loss of integrity of the alveolar-capillary barrier secondary to the intense inflammation in the pleural cavity. ${ }^{10}$

The first mechanism, ie, spilling of inflammatory mediators, is supported by the view that in the pleural cavity, IL-8 levels increase early and decline over time, whereas the opposite is observed in blood. ${ }^{10}$ In parallel, VEGF levels tend to increase progressively in both pleural fluid and blood, reflecting an increase in capillary permeability, which contributes to both the production of pleural fluid and the passage of smaller molecules from the cavity to the blood circulation. We observed that only TGF- $\beta$ levels after instillation of small talc $(50 \%$ of particles $<10 \mu \mathrm{m})$ and VEGF levels after administration of mixed talc $(90 \%$ of particles $>10 \mu \mathrm{m}$ ) presented a strong pleura-serum correlation (Figure 2), suggesting a possible communication between the 2 compartments. ${ }^{30,41-43}$ Despite this observation, these data alone do not permit the inference that this is the only mechanism involved in the systemic response observed in talc pleurodesis.

Comparison of these parameters shows a positive correlation between VEGF and TGF- $\beta$ levels in pleural fluid, demonstrating a possible proinflammatory effect of TGF$\beta$. This possibility has been suggested in a previous study in which TGF- $\beta$ was found to stimulate the production of VEGF by mesothelial cells, a finding explaining in part the increased vascular permeability observed in inflammation

\section{VEGF $(\mathrm{pg} / \mathrm{mL})$ - Mixed Talc $(90 \%>10 \mu \mathrm{m})$}

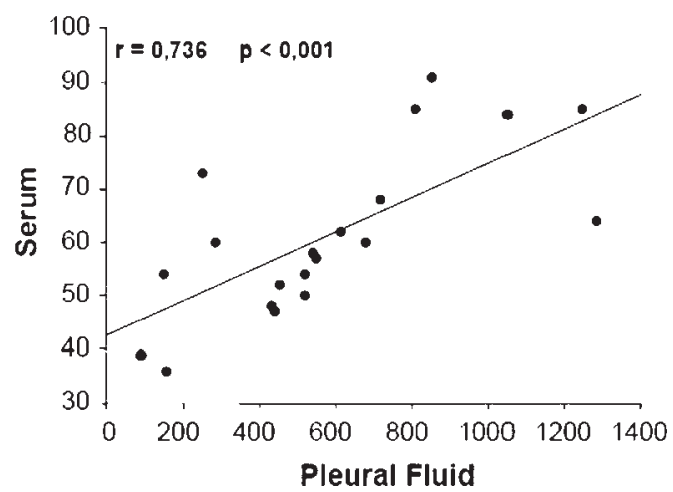

Figure 2 - Comparison of tumor growth factor-beta (TGF- $\beta$ ) and vascular endothelial growth factor (VEGF) levels in pleural fluid and blood of rabbits submitted to intrapleural injection of small-particle talc and mixed talc, respectively. 
after pleurodesis. ${ }^{43}$ However, we observed higher pleural VEGF levels after the administration of small talc $(<5 \mu \mathrm{m})$ compared with mixed talc $(90 \%$ of particles $>10 \mu \mathrm{m})$, whereas TGF- $\beta$ levels were higher in animals injected with mixed talc, suggesting a possible overlapping of distinct inflammatory mechanisms..$^{30,44}$

In addition to inflammatory mediators, an acute serum increase of leukocytes and neutrophils is also observed in both talc groups, coinciding with the acute pleural inflammatory response. However, no conclusion can be drawn about whether the systemic cellular response is the result of the flow of cells from the pleural cavity to the blood circulation or whether it is a direct response to the presence of talc particles in the organs. ${ }^{30,31}$ Therefore, future studies correlating the cellular response with the number of particles deposited in tissues will contribute to clarifying this question.

Another mechanism that might explain the systemic inflammatory response is the direct passage of talc particles from the pleural space into the blood circulation. The presence of talc particles in intrathoracic and extrathoracic tissues has been the subject of many studies. Ferrer et $\mathrm{al}^{27,32}$ suggested that small particles are more easily absorbed by lymphatic stomata (which, in humans, measure about 6.2 $\mu \mathrm{m}$ in diameter ${ }^{26}$ ) and are carried by lymphatic vessels, triggering an inflammatory response that provokes acute lung injury in the form of adult respiratory distress syndrome.
This assumption is justified by the fact that all series in which cases of respiratory insufficiency were reported were from North America (a country presenting the smallest particles among those studied). Curiously, no case of adult respiratory distress syndrome was reported in 2 large series (one European and another Israeli series). ${ }^{24,32}$

Our studies agree with the previously described findings and emphasize the observation that the particles present in the organs studied are all smaller than $5 \mu \mathrm{m}$, suggesting that the systemic effects observed can be explained by the presence of small particles. The same mechanism may explain the systemic effects observed after the administration of mixed talc, since about $10 \%$ of the particles in this type of talc are smaller than $10 \mu \mathrm{m}$. However, if we assume that the probable mechanism of talc particle migration from the pleural cavity to the systemic circulation involves lymphatic absorption, it would be difficult to explain the presence of talc particles in the liver, spleen, and kidney (Figure 3), because these particles enter the systemic venous circulation and return to the lung where they are retained. Therefore, we believe that lymphatic absorption is not the only mechanism involved, and we speculate that the intense inflammation caused by talc promotes the loss of integrity of the capillary barrier, permitting the free flow between the 2 compartments.

These considerations permit us to infer that the mechanism underlying the systemic inflammatory response ob-

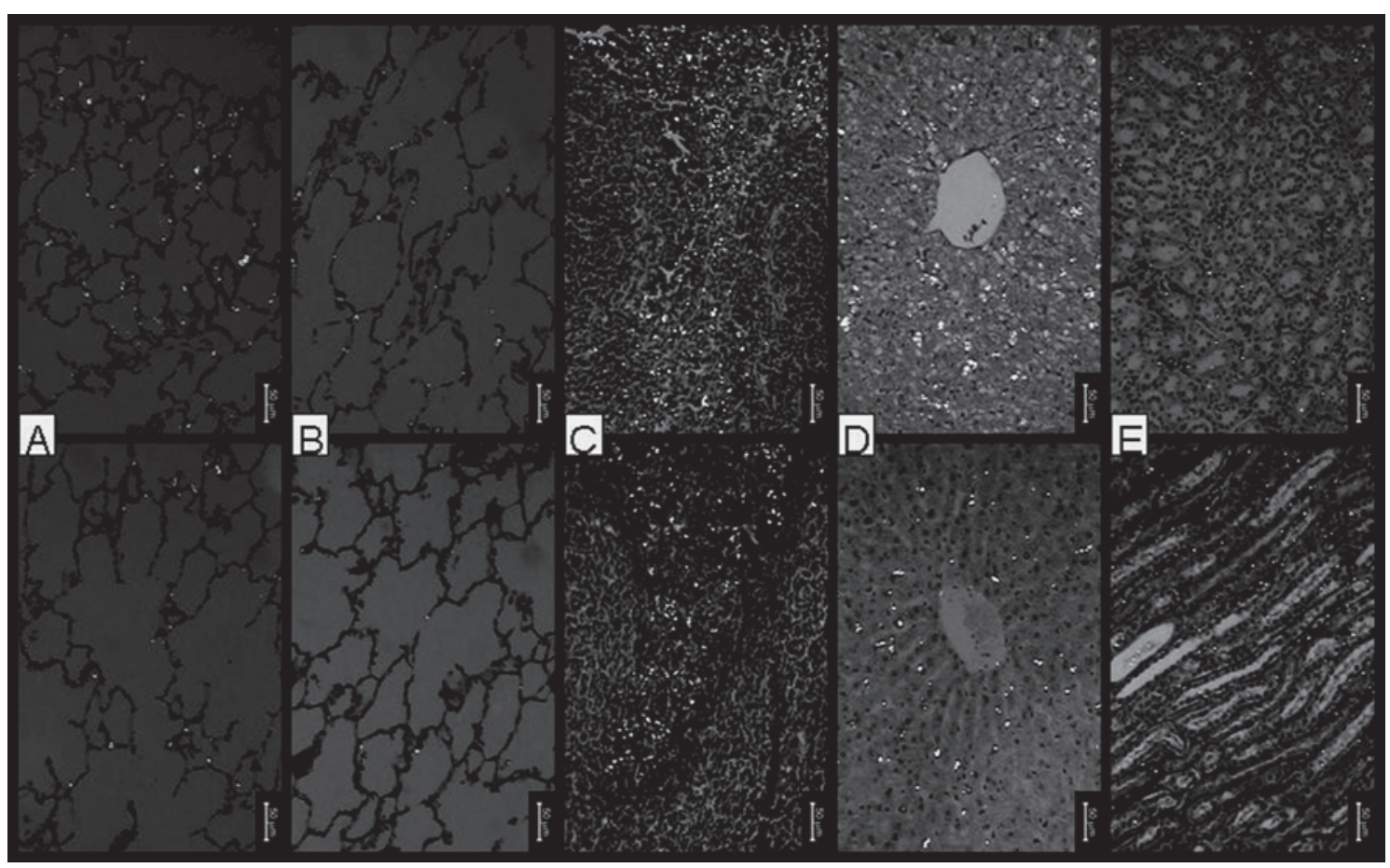

Figure 3 - Photomicrographs of the left (A) and right lung (B), spleen (C), liver (D), and kidney (E) of rabbits submitted to th intrapleural instillation of small-particle talc $(<5 \mu \mathrm{m})$ (upper panel) and mixed talc $(90 \%$ of particles $>10 \mu \mathrm{m})$ (lower panel) obtained after 24 hours (hematoxylin and eosin, polarized light, magnification: x200). Note the scattered birefringent talc particles observed in both images. 
served in talc pleurodesis remains to be established. However, it seems reasonable to assume that particle size influences the inflammatory response and, possibly, the side effects observed in clinical practice, since talc migration to other organs has been demonstrated.

We conclude that talc-containing particles of small size cause more marked pleural inflammation and a greater systemic inflammatory response, accompanied by extrapleural talc deposition in various organs. The mechanisms underlying these phenomena are still not completely understood, and further studies on this subject are necessary, especially those investigating the mechanisms of talc particle migration.

\section{AUTHORS’ NOTE}

The talc used by the Discipline of Pneumology, University of São Paulo Medical School (HC-FMUSP), comprises a wide variation in particle size, with about $10 \%$ consisting of particles smaller than $10 \mu \mathrm{m}$. Considering that about $5 \mathrm{~g}$ of talc is instilled during pleurodesis induction, about $500 \mathrm{mg}$ of this agent comprises particles smaller than $10 \mu \mathrm{m}$. Thus, for a pleural surface of about $2000 \mathrm{~cm}^{2}, 500$ $\mathrm{mg}$ of small-particle talc corresponds to $4 \mathrm{mg} / \mathrm{cm}^{2}$ (4000 $\mu \mathrm{g} / \mathrm{cm}^{2}$ ), a dose considered to be extremely high and potentially toxic to the mesothelium. We demonstrated in cell culture experiments that doses higher than $48 \mu \mathrm{g} / \mathrm{cm}^{2}$ provoke mesothelial cell necrosis. ${ }^{44,45}$

\section{RESUMO}

Genofre EH, Marchi E, Vargas FS. Repercussões clínicas e inflamatórias de pleurodese induzida pela administração intrapleural de talco. Clinics. 2007; 62(5):627-34.

Apesar dos relatos sobre pleurodese remontarem ao início do século XX, ainda hoje se busca o agente esclerosante ideal. Diversos agentes foram estudados e utilizados, mas o talco é considerado o mais popular. No entanto, efeitos sistêmicos potencialmente tóxicos tem sido associados à pleurodese pelo talco. Neste artigo discutimos os prováveis mecanismos de inflamação pleural e pleurodese, com ênfase na resposta sistêmica produzida pela instilação intrapleural de talco

UNITERMOS: Talco. Pleurodese. Inflamação. Pleura. Efusão Pleural.

\section{REFERENCES}

1. Hausheer FH, Yarbro JW. Diagnosis and treatment of malignant pleural effusion. Semi Oncol. 1985;12:54-75.

2. Marchi E, Teixeira LR, Vargas FS. Management of malignancyassociated pleural effusion: current and future treatment strategies. Am J Respir Med. 2003;2:261-73.
3. Bethune N. Pleural poudrage: new technique for deliberate production of pleural adhesions as preliminary to lobectomy. J Thorac Surg. 1935;4:251-61.

4. Vargas FS, Teixeira LR, Marchi E. Pleural effusion, $1^{\text {st }}$ ed, Ed Roca, 2004. 
5. Wallach HW. Intrapleural tetracycline for malignant pleural effusions. Chest. 1975;68:510-2.

6. Teixeira LR, Vargas FS, Acencio MMP, Bumlai RUM, Antonangelo L, Marchi E. Experimental pleurodesis induced by antibiotics (macrolides or quinolones). Clinics 2006;61:559-64.

7. Bitran JD, Brown C, Desser RK, Kozloff MF, Shapiro C, Billings AA Intracavitary bleomycin for the control of malignant effusions. J Surg Oncol. 1981;16:273-6.

8. Rossi GA, Felletti R, Balbi B, Sacco O, Cosulich E, Risso A, et al Symptomatic treatment of recurrent malignant pleural effusions with intrapleurally administered Corynebacterium parvum. Am Rev Respir Dis. 1987:135:885-90

9. Kishi K, Homma S, Sakamoto S, Kawabata M, Tsuboi E, Kohno T, et al. Efficacious pleurodesis with OK-432 and doxorubicin against malignant pleural effusions. Eur Respir J, 2004;24:263-6.

10. Marchi E, Vargas FS, Acencio MMP, Antonangelo L, Teixeira LR, Genofre $\mathrm{EH}$, et al. Talc and silver nitrate induce systemic inflammatory effects during the acute phase of experimental pleurodesis in rabbits. Chest. 2004;125:2268-77.

11. Vargas FS, Teixeira LR, Antonangelo L, Vaz MAC, Carmo AO, Marchi $\mathrm{E}$, et al. Experimental pleurodesis in rabbits induced by silver nitrate and talc. 1-year follow-up. Chest. 2001;119:1516-20.

12. Gary Lee YC, Malkerneker D, Devin CJ, Thompson PJ, Johnson JE, Lane KB, et al. Comparing transforming growth factor beta- 2 and fibronectin as pleurodesing agents. Respirology. 2001;6:281-6.

13. Sartori S, Tassinari D, Ceccotti P, Tombesi P, Nielsen I, Trevisani L, et al. Prospective randomized trial of intrapleural bleomycin versus interferon alfa- $2 \mathrm{~b}$ via ultrasound-guided small-bore chest tube in the palliative treatment of malignant pleural effusions. J Clin Oncol. $2004 ; 22: 1228-33$

14. Brissaud O, Desfrere L, Mohsen R, Fayon M, Demarquez JL. Congenital idiopathic chylothorax in neonates: chemical pleurodesis with povidoneiodine (Betadine). Arch Dis Child Fetal Neonatal Ed. 2003;88:F531-3.

15. Lang-Lazdunski L, Coonar AS. A prospective study of autologous 'blood patch' pleurodesis for persistent air leak after pulmonary resection. Eur J Cardiothorac Surg. 2004;26:897-900.

16. Cetin B, Koçkaya EA, Atalay C, Akay MT, Cetin A. The efficacy of polidocanol in pleurodesis in rats. Surg Today. 2003;33:688-92.

17. de Campos JR, Vargas FS, Werebe EC, Cardoso P, Teixeira LR, Jatene FB, et al. Thoracoscopy talc poudrage: a 15 -year experience. Chest. 2001;119:801-6.

18. Light RW. Talc for pleurodesis? Chest. 2002;122:1506-8.

19. Sahn SA. Talc should be used for pleurodesis: pro/con editorials. Am J Respir Crit Care Med. 2001;163:2023-6.

20. de Campos JR, Werebe EC, Vargas FS, Jatene FB, Light RW. Respiratory failure due to insufflated talc. Lancet. 1997;349:251-2.

21. Rehse DH, Aye RW, Florence MG. Respiratory failure after talc pleurodesis. Am J Surg. 1999;177:437-40.

22. Todd TR, Delarue NC, Ilves R, Pearson FG, Cooper JD, et al. Talc poudrage for malignant pleural effusion. Chest. 1980;78:542-3.

23. Marchi E, Teixeira LR, Vargas FS, Astoul P, Fraticelli A, Robaglia-Schlupp A, et al. Talc for pleurodesis: hero or villain? Chest. 2003;124:416.
24. Van der Heuvel MM, Smith HJ, Barbierato SB, Havenith CE, Beelen RH, Postmus PE. Talc-induced inflammation in the pleural cavity. Eur Resp J. 1998;12:1419-23.

25. Montes JF, Ferrer J, Villarino MA, Baeza B, Crespo M, Garcia-Valero J Influence of talc dose on extrapleural talc dissemination after talc pleurodesis. Am J Respir Crit Care Med. 2003;168:348-55

26. Li J. Ultrastructural study on the pleural stomata in human. Funct Dev Morphol. 1993;3:277-80.

27. Ferrer J, Montes JF, Villarino MA, Light RW, Garcia-Valero J. Influence of particle size on extrapleural talc dissemination after talc slurry pleurodesis. Chest. 2002;122:1018-27.

28. Werebe EC, Pazetti R, de Campos JR, Fernandez PP, Capelozzi VL, Jatene FB, et al. Systemic distribution of talc after intrapleural administration in rats. Chest. 1999;115:190-3.

29. Fraticelli A, Robaglia-Schlupp A, Riera H, Monjanel-Mouterde S, Cau P, Astoul P. Distribution of calibrated talc after intrapleural administration: an experimental study in rats. Chest. 2002;122:173741

30. Genofre EH, Vargas FS, Teixeira LR, Acencio MMP, Antonangelo L, Marchi E. Systemic inflammatory acute response in talc pleurodesis using talc of different size particles. Chest. 2004;126:726S

31. Genofre EH, Vargas FS, Acencio MMP, Antonangelo L, Teixeira LR, Figueiredo VR, et al. Talc pleurodesis: lung dispersion of talc using talc of different size particles. Eur Respir J. 2006;28:740s.

32. Ferrer J, Villarino MA, Tura JM, Traveria A, Light RW. Talc preparations used for pleurodesis vary markedly from one preparation to another. Chest. 2001;119:1901-5.

33. Genofre EH, Vargas FS, Antonangelo L, Teixeira LR, Vaz MA, Marchi E, et al. Ultrastructural acute features of active remodeling after chemical pleurodesis induced by silver nitrate or talc. Lung. 2005;183:197-207.

34. Maskell NA, Gleeson FV, Jones E, Davies RJ. Talc but not tetracycline pleurodesis induces hypoxemia and increased DTPA clearance from the contra-lateral lung. Am J Respir Crit Care Med. 2002;165:B11.

35. Maskell NA, Lee YC, Gleeson FV, Hedley EL, Pengelly G, Davies RJ. Randomized trials describing lung inflammation after pleurodesis with talc of varying particle size. Am J Respir Crit Care Med. 2004;170:37782

36. Kwek BH, Aquino SL, Fischman AJ. Fluorodeoxyglucose positron emission tomography and CT after talc pleurodesis. Chest. 2004;125:2356-60.

37. Gary Lee YC. Cytokines in pleural diseases. In Light RW, Lee YC: Textbook of pleural diseases. London: Arnold Publishers; 2003. p. $63-$ 89.

38. Gary Lee YC, Lane KB, Zoia O, Thompson PJ, Light RW, Blackwell TS. Transforming growth factor-beta induces collagen synthesis without inducing IL-8 production in mesothelial cells. Eur Respir J. 2003;22:197-202.

39. Sanches C, Marchi E, Romero B, Vargas FS, Panadero FR. Association of the size of talc particles with the occurrence of complications of pleurodesis. Eur Respir J. 2001;18:515-6S

40. Nasreen N, Mohammed KA, Dowling PA, Ward MJ, Galffy G, Antony VB. Talc induces apoptosis in human malignant mesothelioma cells in vitro. Am J Respir Crit Care Med. 2000;161:595-600. 
41. Froudarakis ME, Klimathianaki M, Pougonias M. Systemic inflammatory reaction after thoracoscopic talc poudrage. Chest. 2006;129:356-61.

42. Segura RM, Alegre J, Varela E, Marti R, Suriñach JM, Jufresa J, et al. Interleukin-8 and markers of neutrophil degranulation in pleural effusions. Am J Respir Crit Care Med. 1998;157:1565-72.

43. Gary Lee YC, Melkerneker D, Thompson PJ, Light RW, Lane KB. Transforming growth factor ${ }^{2}$ induces vascular endothelial growth factor elaboration from pleural mesothelial cells in vivo and in vitro. Am J Respir Crit Care Med. 2002;165:88-94.
44. Marchi E, Vargas FS, Acencio MM, Antonangelo L, Genofre EH, Teixeira LR. Evidence that mesothelial cells regulate the acute inflammatory response in talc pleurodesis. Eur Respir J. 2006;28:92932.

45. Acencio MMP, Vargas FS, Teixeira LR, Antonangelo L, Marchi E. Are mesothelial cells the key regulators of the acute inflammatory response in talc-induced pleurodesis? Am J Respir Crit Care Med. 2004;169:A618. 